\title{
Temperature, $\mathrm{pH}$ and bile dependent in vitro cultivation of Hexamita salmonis from rainbow trout Oncorhynchus mykiss intestine
}

\author{
Kurt Buchmann*, Anders Uldal \\ Department of Veterinary Microbiology, Section of Fish Diseases, Royal Veterinary and Agricultural University, \\ 13 Bülowsvej, DK-1870 Frederiksberg C, Denmark
}

\begin{abstract}
The intestinal diplomonadid flagellate Hexamita salmonis was isolated from the intestinal contents of freshwater reared raınbow trout Oncorhynchus mykiss in Denmark and maintained in axenic cultures in the laboratory. A cell culture medium (MEM) or MEM supplemented with a bile solution (Keister's modified TYI-S-33) and penicillin, gentamicin and nystatin (mycostatin) was used as culture substrate. Temperature, $\mathrm{pH}$ and bile requirements for laboratory maintenance were investigated. Optimum temperature for $\mathrm{H}$. salmonis population increase was determined to be $10^{\circ} \mathrm{C}$. Satisfactory although decreased growth was found at $5^{\circ} \mathrm{C}$. At $15^{\circ} \mathrm{C}$ and $20^{\circ} \mathrm{C}$ flagellate cells survived but did not exhibit significant population growth. In the $\mathrm{pH}$ range from 4 to 10 parasite survival was seen from 5.5 to 9.0, although optimum pH conditions for population uncrease were pH 7.5 to 8.0 . Bile in low concentrations ( 30 to $960 \mathrm{mg} \mathrm{l}^{-1}$ ) enhanced flagellate propagation slightly. This study on the basic requirements explains the occurrence of the flagellate in rainbow trout in less warm seasons and biotopes as well as particular microhabitats in the host.
\end{abstract}

KEY WORDS: Hexamita salmonis Parasite Protozoa Diplomonadida In vitro cultivation Rainbow trout $\cdot$ Oncorhynchus mykiss $\cdot$ MEM - TYI-S-33

\section{INTRODUCTION}

The intestinal diplomonadid flagellate Hexamita salmonis Moore, 1923, has been recorded from a range of salmonid hosts (Lom \& Dyková 1992, Woo \& Poynton 1995) and is often found associated with pathogenic conditions in hatchery fish (Moore 1923, Davis 1956, Ferguson 1979). The pathogenicity of this protozoan has been doubted by some authors and experiments have been performed to elucidate this point (Uzmann et al. 1965). However, a crucial point in this dispute is to determine the basic growth requirement of $H$. salmonis itself, information which for the most part is lacking. This will also contribute to an understanding of the parasite's site selection in the host and the seasonal variation in occurrence (Rosen-

·E-mail: kurt.buchmann@vetmi.kvl.dk garten 1985, Uldal \& Buchmann unpubl.). A valuable approach in this regard is in vitro cultivation of the organism in question. Following development of culture methods for the related genus Giardia (Karapetyan 1962, Meyer 1976, Keister 1983), a wide range of isolates have been characterized biochemically and biologically. This has demonstrated differing strain characteristics (Thompson et al. 1994). Similar variations are likely to be found in $H$. salmonis. The first cultivation of a $H$. salmonis strain using human cord serum in a culture medium was achieved by Uzmann \& Hayduk (1963) and subsequently an evaluation of the pathogenicity of particular isolate was performed (Uzmann et al. 1965). In the present paper we present a new easy culture technique for $H$. salmonis, the isolation and cultivation of a Danish strain of this protozoan species and the subsequent determination of temperature, $\mathrm{pH}$ and bile requirements for this particular parasite strain. 


\section{MATERIALS AND METHODS}

Parasite isolation. A total of 8 specimens of Oncorhynchus mykiss fry ( 4 to $5 \mathrm{~cm}$ total body length) heavily infected with Hexamita salmonis and kept at $7.8^{\circ} \mathrm{C}$ were dissected. The entire intestine including the pyloric region with content was removed from each fish and placed in a $250 \mathrm{ml}$ screw cap glass culture flask containing $145 \mathrm{ml}$ culture medium. The culture flask with medium and 8 intestines were then incubated at $7.8^{\circ} \mathrm{C}$ for $28 \mathrm{~d}$. Thereafter the parasite culture was subcultivated by transferring the cell culture suspension to screw cap glass tubes (dilution 1:3) or screw cap glass culture flasks with new medium, which were incubated for $5 \mathrm{~d}$ at $7.8^{\circ} \mathrm{C}$. From this stage further subcultivations could be conducted by transferring the parasite cell culture to new medium (dilution 1:5). Addition of nitrogen gas was not used.

Culture medium. The medium was composed of Eagle's Minimum Essential Medium (MEM) (Sigma Cat. No. M 0643) supplemented with $10 \%$ foetal bovine serum (Gibco BRL Cat. No. 10106-078), inactivated at $56^{\circ} \mathrm{C}$ for $30 \mathrm{~min}$, and $4 \%$ Keister's modified bile-supplemented TYI-S-33 medium (Keister 1983). For isolation of parasites $\mathrm{pH}$ was adjusted to 7.5. Inhibition of bacterial and fungal growth was achieved by adding the antibiotics penicillin (2000 $\mathrm{U} \mathrm{ml}^{-1}$ ), gentamicin $\left(50 \mu \mathrm{g} \mathrm{ml}^{-1}\right)$ and nystatin (mycostatin) $\left(100 \mathrm{U} \mathrm{ml}^{-1}\right)$.

This medium but without the addition of bile-supplemented TYI-S-33 was used when studying the influence of bile addition on the growth of Hexamita salmonis populations.

Parasite cell counting. To determine the concentration of Hexamita salmonis cells in culture flasks the content was thoroughly stirred and aliquots of 1 to $15 \mathrm{\mu l}$ were placed on slides under a $12 \times 12 \mathrm{~mm}$ coverslip and counted using a light microscope at a magnification of 100 to $250 \times$. Only motile cells were included and each determination included 3 to 5 subsamples. The concentration of cells m.l $\mathrm{l}^{-1}$ was then calculated.

Determination of temperature optimum. A parasite cell culture ( 5000 cells $\left.\mathrm{ml}^{-1}\right)$ was established and duplicates of $88 \mathrm{ml}$ cell culture in $250 \mathrm{ml}$ glass flasks were placed in thermostat-regulated incubators at $5,10,15$ and $20^{\circ} \mathrm{C}$ without light. Parasite cell concentrations in individual culture flasks were determined at intervals of a few days for $18 \mathrm{~d}$. The flagellates survived well the transfer from $7.8^{\circ} \mathrm{C}$ to this range of temperatures

Determination of $\mathrm{pH}$ optimum. Parasite cell cultures $\left(150 \mathrm{ml}, 10000\right.$ cells $\left.\mathrm{ml}^{-1}\right)$ were established in $250 \mathrm{ml}$ flasks and $\mathrm{pH}$ was adjusted gradually over $48 \mathrm{~h}$ from 7.5 to the appropriate final incubation $\mathrm{pH}: 4.0,4.5,5.0$, $5.5,6.0,6.5,7.0,7.5,8.0,8.5,9.0,9.5$ or 10.0 . The cultures were incubated at $10^{\circ} \mathrm{C}$ in a thermostat-regulated incubator and parasite cell concentrations were determined at intervals of a few days for the following $14 \mathrm{~d}$.

Determination of bile requirements. A total of 15 cell cultures $\left(100 \mathrm{ml}, 20000\right.$ cells $\left.\mathrm{ml}^{-1}\right)$ were established. Two cultures did not contain bile, 2 contained $4 \%$ Keister's medium, and the remaining 11 flasks contained bile (bovine Sigma B-8381) in increasing concentrations from 30 to $29120 \mathrm{mg} \mathrm{l}^{-1}$ ).

\section{RESULTS}

\section{Temperature optimum}

At both 5 and $10^{\circ} \mathrm{C}$ the cell cultures multiplied rapidly. After inoculation a laq phase of a few days was observed. This was then replaced by an exponential growth phase and finally a maximum was seen, followed by a more or less slight decrease (Fig. 1).

The population increase of Hexamita salmonis was pronounced and fastest at $10^{\circ} \mathrm{C}$. Within $10 \mathrm{~d}$ the duplicate cell cultures reached a maximum of 250000 and 290000 cells $\mathrm{ml}^{-1}$, respectively. At $5^{\circ} \mathrm{C}$ the growth curve was less steep and the maximum cell concentrations (180000 and 215000 cells $\mathrm{ml}^{-1}$ ) were achieved only after $15 \mathrm{~d}$.

At both 15 and $20^{\circ} \mathrm{C}$ an initial decline in parasite count was replaced after $10 \mathrm{~d}$ by a steady low-count parasite population (less than 8000 and 2000 cells ml $^{-1}$, respectively)

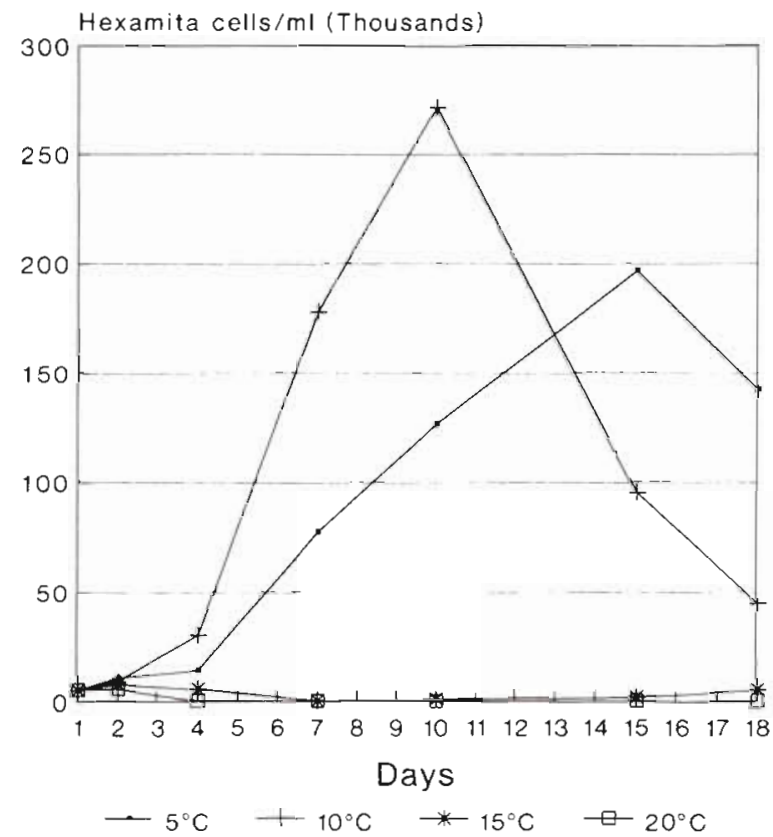

Fig. 1 Temperature dependent, in vitro population increase of Hexamita salmonis in MEM with $4 \%$ Keister's medium and $10 \%$ foetal calf serum ( $\mathrm{pH} 7.5$ ) (means of duplicate groups) 


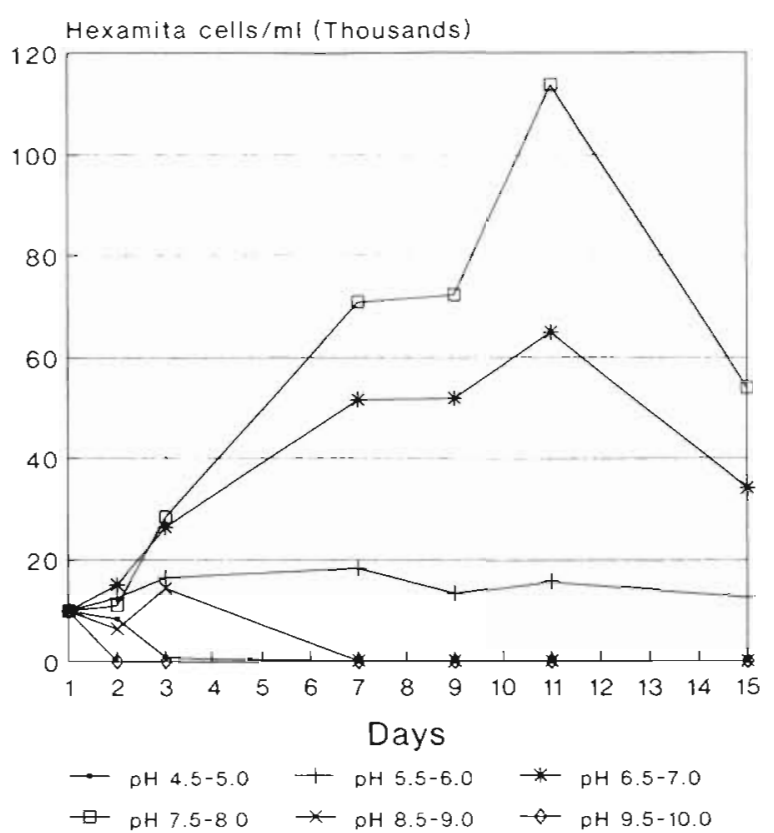

Fig. 2. The pH dependent, in vitro population increase of Hexamita salmonis in MEM with $4 \%$ Keister's medium and $10 \%$ foetal calf serum (temperature $10^{\circ} \mathrm{C}$ ) (means of 2 groups in each interval!

\section{pH optimum}

The fastest growth rates were observed at $\mathrm{pH} 7.5$ and 8.0, at which cell counts above 110000 cells $\mathrm{ml}^{-1}$ were seen (Fig. 2). Above this $\mathrm{pH}$ ( $\mathrm{pH} 8.5$ and 9.0) cell counts decreased rapidly to below 100 cells $\mathrm{ml}^{-1}$. At lower $\mathrm{pH}$ values ( $\mathrm{pH} 6.0$ and 5.5) maximum counts did not exceed 27000 and 10000 cells $\mathrm{ml}^{-1}$. respectively (Fig. 2). The lowest $\mathrm{pH}$ values were unsuitable for Hexamita salmonis. No survival of cells was observed after $3 \mathrm{~d}$ at $\mathrm{pH} 4.5$ and 5.0, and at $\mathrm{pH} 4.0$ all cells were killed within $24 \mathrm{~h}$. This was also observed at pH 9.5 and 10.0 .

\section{Bile requirements}

All cell cultures replicated slowly during the first $5 \mathrm{~d}$ whereafter cultures containing from 30 to $960 \mathrm{mg}$ bile $\mathrm{I}^{-1}$ exhibited superior growth performance compared to either higher or no bile concentration (Fig. 3). The MEM alone supported satisfactory growth of Hexamita salmonis but addition of moderate bile amounts or $4 \%$ Keister's medium seemed to augment growth moderately. Bile concentrations of 3600 and $14000 \mathrm{mg} \mathrm{l}^{-1}$ were associated with a steady decline in cell counts during the $8 \mathrm{~d}$ following inoculation. Concentrations above this level (29120 $\mathrm{mg} \mathrm{l}^{-1}$ ) were lethal to the cell cultures within a few hours.

\section{DISCUSSION}

A number of field studies have indicated that the Hexamita salmonis organisms in salmonids exhibit seasonal occurrence (Moore 1923, Davis 1956) and select particular microhabitats in the host intestine (Moore 1923, Davis 1956, Ferguson 1979, Poynton 1986, Buchmann et al. 1995, Uldal \& Buchmann unpubl.). Satisfactory explanations of these observations are, however, not available. The present in vitro cultivation method provides us with a tool to elucidate the basic biological characteristics of this diplomonadid flagellate.

Using this method, it was evident that temperature has a crucial influence on Hexamita salmonis multiplication. With inferior growth at 15 and $20^{\circ} \mathrm{C}$, optimal performance at $10^{\circ} \mathrm{C}$ and significant growth at $5^{\circ} \mathrm{C}$ it is evident that this flagellate is adapted to lower temperatures. This can explain the pronounced occurrence of the parasite in winter, spring and early summer (Davis 1956. Buchmann et al. 1995) and its subsequent survival in summer. Comparative temperature experiments were not presented by Uzmann \& Hayduk (1963) although they chose to cultivate the organism at $10^{\circ} \mathrm{C}$.

Hexamita salmonis is known to occupy restricted microhabitats in the host's intestinal tract (Moore 1923,

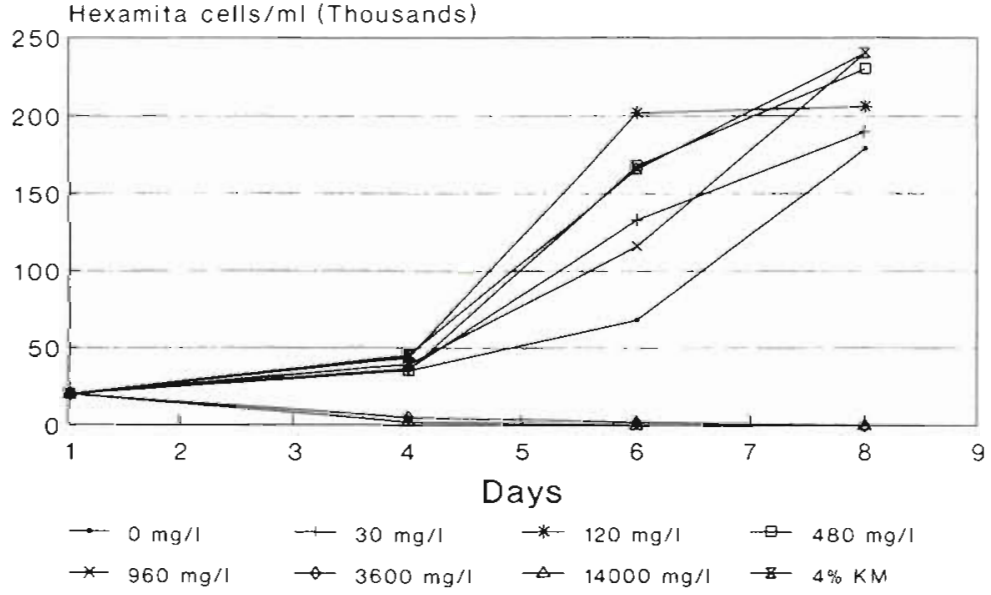

Fig. 3. Bile dependent, in vitro population increase of Hexamita salmonis in MEM with $10 \%$ foetal calf serum. Bile was added in concentrations from 30 to $14000 \mathrm{mg} \mathrm{l}^{-1}$ (pH 7.5). The $29120 \mathrm{mg} \mathrm{l}^{-1}$ culture died within a few hours. Cultures with no bile addition and with $4 \%$ Keister's medium (KM) (means of duplicates) are also shown 
Uldal \& Buchmann unpubl.). Whether this is due to the parasite's special requirements (Uldal \& Buchmann unpubl.) or related to the age of the infection (Moore 1923 ) is unknown. The present observations on $\mathrm{pH}$ and bile dependent growth suggest that $H$. salmonis is well adapted to the anterior part of the intestine. Relatively low $\mathrm{pH}$ values ( $\mathrm{pH} \mathrm{6)}$ (due to the inlet of acidic stomach contents into the anterior intestine and pyloric region) are well tolerated by the organism, although neutral and slightly basic conditions are optimal ( 7.0 to 8.0 ). Although the present in vitro studies demonstrated that serum-complemented MEM alone will support growth satisfactorily, the addition of low amounts of bile augments flagellate population increase. This could also explain the location of these diplomonadids in the anterior part of the intestine. The TYI-S-33 medium (Keister 1983) alone did not appear to support growth of the $H$. salmonis strains studied (data not shown). Judging from the maximum number of cells recorded in our culture flasks (290000 cells ml-1) it appears that the MEM medium supplemented with Keister's medium is superior to the medium (100000 cells $\mathrm{ml}^{-1}$ ) used by Uzmann \& Hayduk (1963). However, parasite strain differences and incubation method may influence this variation.

During recent years systemic infections of salmonids with Hexamita salmonis-like organisms have been reported (Mo et al. 1990, Kent et al. 1992, Poppe et al. 1992). Biological, biochemical and molecular comparative studies using the described in vitro technique could contribute significantly to the elucidation of relations and affiliations between intestinal and systemic organisms.

Acknowledgements. This study was supported by the Danish Agricultural and Veterinary Research Council. The skilful technical assistance of Mrs Lotte Nicolaisen is highly appreciated.

\section{LITERATURE CITED}

Buchmann K, Uldal A, Lyholt HCK (1995) Parasite infections in Danish trout farms. Acta Vet Scand 36:283-298

Responsible Subject Editor: W. Korting, Hannover, Germany
Davis HS (1956) Culture and diseases of game fishes. University of California Press, Berkeley

Ferguson HW (1979) Scanning and transmission electron microscopical observations on Hexamita salmonis (Moore. 1922) related to mortalities in rainbow trout try Salmo gairdneri Richardson. J Fish Dis 2:57-67

Karapetyan AE (1962) In vitro cultivation of Giardia duodenalis. J Parasitol 48:337-340

Keister DB (1983) Axenic culture of Giardia lamblia in TYI-S33 medium supplemented with bile. Trans R Soc Trop Med Hyg 77:487-488

Kent ML, Ellis J, Fournie JW, Dawe SC, Bagshaw JW, Whitaker DJ (1992) Systemic hexamitid (Protozoa: Diplomonadidal infection in seawater pen-reared chinook salmon Oncorhynchus tshawytscha. Dis Aquat Org 14: $81-89$

Lom J, Dykova I (1992) Protozoan parasites of fishes. Dev Aquacult Fish Sci 26:1-315

Meyer EA (1976) Giardia lamblia: isolation and axenic culiiváliurl. Exp Parasitul 39:10i-10j

Mo TA, Poppe TT, Iversen L (1990) Systemic hexamitosis in saltwater reared Atlantic salmon (Salmo salar L.). Bull Eur Ass Fish Pathol 10:69-70

Moore E (1923) Octomitus salmonis, a new species of intestinal parasite in trout. Trans Am Fish Soc 54:74-93

Poppe TT, Mo TA, Iversen L (1992) Disseminated hexamitosis in seacaged Atlantic salmon Salmo salar. Dis Aquat Org 14:91-97

Poynton SL (1986) Distribution of the flagellate Hexamita salmonis Moore, 1922 and the microsporidian Loma salmonae Putz, Hoffman and Dunbar, 1965 in brown trout, Salmo trutta L., and rainbow trout, Salmo gairdner Richardson, in the River Itchen (U.K.) and three of its farms. J Fish Biol 29:417-429

Rosengarten R (1985) Parasitologische Untersuchungen an Regenbogenforellen (Salmo gairdneri Richardson) in einer Forellenteichwirtschaft in Westniedersachsen. DVM dissertation, Tierärztliche Hochschule Hannover

Thompson RCA, Reynoldson JA, Lymbery AJ (1994) Giardia: from molecules to disease. CAB International, Wallingford, Oxon

Uzmann JR, Hayduk SH (1963) In vitro culture of the flagellate protozoan Hexamita salmonis. Science 140:290-292

Uzmann JR, Paulik GJ, Hayduk SH (1965) Experimental hexamitiasis in juvenile coho salmon (Oncorhynchus kisutch) and steelhead trout (Salmo gairdneri). Trans Am Fish Soc 94:53-61

Woo PTK, Poynton SL (1995) Diplomonadida, Kinetoplastida and Amoebida (Phylum Sarcomastigophora). In: Woo PTK (ed) Fish diseases and disorders, 1, Protozoan and metazoan infections. $C A B$ International, Wallingford, Oxon

Manuscript first received: August 20, 1995 Revised version accepted: October 23, 1995 